\begin{tabular}{|c|c|c|c|c|c|}
\hline \multicolumn{6}{|c|}{ DISTRIBUTION SHEET } \\
\hline \multirow{2}{*}{$\begin{array}{l}\text { To } \\
\text { Distribution }\end{array}$} & \multirow{2}{*}{\multicolumn{3}{|c|}{$\begin{array}{l}\text { From } \\
\text { AS, Planning \& Integration }\end{array}$}} & \multicolumn{2}{|l|}{ Page 1 of 1} \\
\hline & & & & \multicolumn{2}{|c|}{ Date Feb 24, 1995} \\
\hline \multirow{2}{*}{\multicolumn{4}{|c|}{$\begin{array}{l}\text { Project Title/Work Order } \\
\text { Hanford Transuranic Analytical Capability }\end{array}$}} & \multicolumn{2}{|c|}{ EDT No. 607158} \\
\hline & & & & \multicolumn{2}{|l|}{ ECN No. $\quad N / A$} \\
\hline Name & MSIN & $\begin{array}{c}\text { Text } \\
\text { With All } \\
\text { Attach. }\end{array}$ & Text Only & $\begin{array}{l}\text { Attach./ } \\
\text { Appendix } \\
\text { Only }\end{array}$ & $\begin{array}{l}\text { EDT/ECN } \\
\text { Only }\end{array}$ \\
\hline $\begin{array}{l}\text { Akita, R. } \\
\text { Bel1, M. L. } \\
\text { Brey, S. L. } \\
\text { Deichman, J. L. } \\
\text { Joyce, S. M. } \\
\text { Kosiancic, E. J. } \\
\text { Marshall Jr., R. P. } \\
\text { McVey, C. B. } \\
\text { Robertson, R. L. } \\
\text { Seidel, C. M. } \\
\text { Spohr, R. A. } \\
\text { Stroup, C. R. } \\
\text { Centrai Files } \\
\text { OSTI }\end{array}$ & $\begin{array}{l}\text { T6-20 } \\
\text { T6-03 } \\
\text { T6-12 } \\
H 4-19 \\
H 4-21 \\
\text { T6-16 } \\
\text { T6-14 } \\
H 4-21 \\
\text { T6-12 } \\
\text { H4-19 } \\
\text { H4-21 } \\
\text { H4-25 } \\
\text { L8- }-8 \\
\text { L8-07 }\end{array}$ & $\begin{array}{l}x \\
x \\
x \\
x \\
x \\
x \\
x \\
(3) \\
x \\
x \\
x \\
x \\
(2) \\
x(2)\end{array}$ & . & & \\
\hline
\end{tabular}




\section{DISCLAIMER}

Portions of this document may be illegible in electronic image products. Images are produced from the best available original document. 


\begin{tabular}{l|l} 
2. To: (Receiving Organization) & 3. From: coriginating Organization) \\
Distribution & AS, Planning and Integration \\
\hline 5. Proj./Prog./Dept./Div.: & 6. Cog. Engr.: \\
WM/AS & C. B. McVey \\
\hline
\end{tabular}

8. Originator Remarks:

This document contains the recommendation for an interim solution for the separation and analys is of Transuranic waste in excess of $200 \mathrm{nCj} / \mathrm{gm}$.

11. Receiver Remarks:

4. Related EDT No.:

$\mathrm{N} / \mathrm{A}$

7. Purchase Order No.:

$N / A$

9. Equip./Component No.:

$\mathrm{N} / \mathrm{A}$

10. System/Bldg./Facility: 222-S

12. Major Assm. Dwg. No.: $N / A$

13. Permit/Permit Application No.: $N / A$

14. Required Response Date:

$$
N / A
$$

\begin{tabular}{|c|c|c|c|c|c|c|c|c|}
\hline 15. & & $D A T$ & NSMIT & & (F) & (G) & (H) & (1) \\
\hline $\begin{array}{l}\text { (A) } \\
\text { Item } \\
\text { No. }\end{array}$ & (B) Document/Drawing No. & $\begin{array}{l}\text { (C) } \\
\text { Sheet } \\
\text { No. }\end{array}$ & $\begin{array}{l}\text { (D) } \\
\text { Rev. } \\
\text { No. }\end{array}$ & $\begin{array}{c}\text { (E) Title or Description of Data } \\
\text { Transmitted }\end{array}$ & $\begin{array}{l}\text { Approval } \\
\text { Desig- } \\
\text { nator }\end{array}$ & $\begin{array}{c}\text { Reason } \\
\text { for } \\
\text { Trans- } \\
\text { mittal }\end{array}$ & $\begin{array}{c}\text { Origi- } \\
\text { nator } \\
\text { Dispo- } \\
\text { sition }\end{array}$ & $\begin{array}{c}\text { Receiv- } \\
\text { or } \\
\text { Dispo- } \\
\text { sition }\end{array}$ \\
\hline 1 & WHC-SD-WM-ES-336 & & 0 & $\begin{array}{l}\text { Hanford Transuranic } \\
\text { Analytical Capability }\end{array}$ & $\mathrm{NA}$ & 1,2 & 1 & \\
\hline & & & & & & & & \\
\hline & & & & & & & & \\
\hline & & & & & & & & \\
\hline & & & & & & & & \\
\hline & & & & & & & & \\
\hline
\end{tabular}

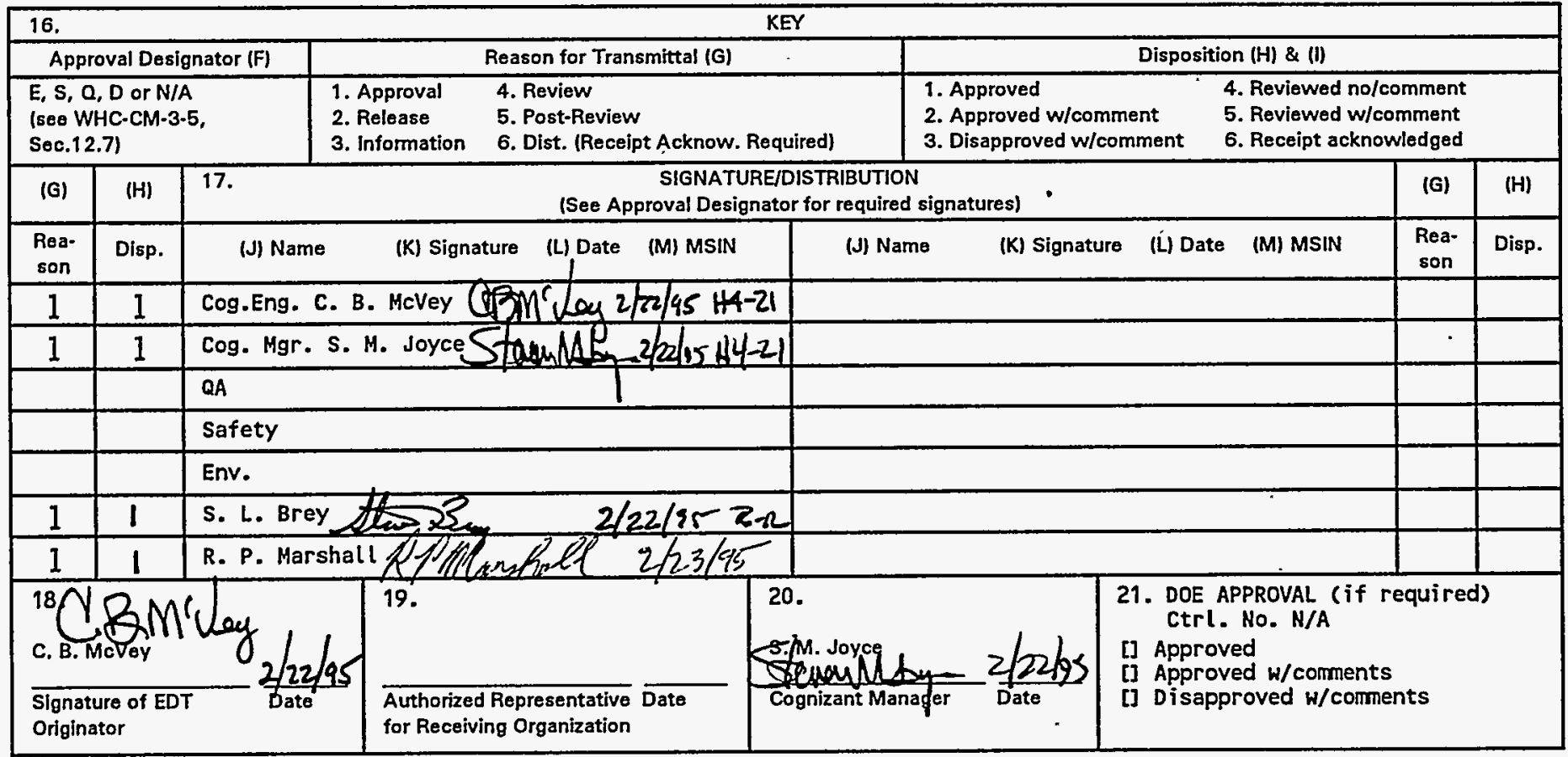




\section{RELEASE AUTHORIZATION}

Document Number: WHC-SD-WM-ES-336, REV. 0

Document Title: HANFORD TRANSURANIC ANALYTICAL CAPABILITY

Release Date: $\quad 2 / 24 / 95$

\section{This document was reviewed following the procedures described in WHC-CM-3-4 and is:}

\section{APPROVED FOR PUBLIC RELEASE}

WHC Information Release Administration Specialist:

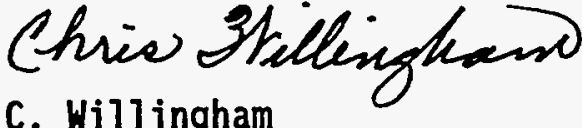

C. Willingham

TRADEMARK DISCLAIMER. Reference herein to any specific commercial product, process, or service by trade neme, trodemark, manufacturer, or otherwise, does not necessarily constitute or imply its endorsement, recomendation, or favoring by the United States Government or any agency thereof or its contractors or subcontractors.

This report has been reproduced fron the best available copy. Available in paper copy and microfiche. Printed in the United States of America. Available to the U.S. Department of Energy and its contractors from:

U.S. Department of Energy Office of Scientific and Technical Information (OSTI)

P.0. BOX 62

Dak Ridge, TH 37831

Telephone: (615) 576-8401

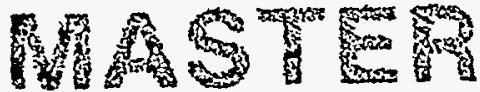

Available to the public from:

U.S. Department of Commerce

National Technical Information Service (NTIS)

5285 Port Royal Road

Springfield, va 22161

Telephone: (703) 487-4650

\section{DISCLAIMER}

This report was prepared as an account of work sponsored by an agency of the United States Government. Neither the United States Government nor any agency thereof, nor any of their employees, makes any warranty, express or implied, or assumes any legal liability or responsibility for the accuracy, completeness, or usefulness of any information, apparatus, product, or process disclosed, or represents that its use would not infringe privately owned rights. Reference herein to any specific commercial product, process, or service by trade name, trademark, manufacturer, or otherwise does not necessarily constitute or imply its endorsement, recommendation, or favoring by the United States Government or any agency thereof. The views and opinions of authors expressed herein do not necessarily state or reflect those of the United States Government or any agency thereof. 


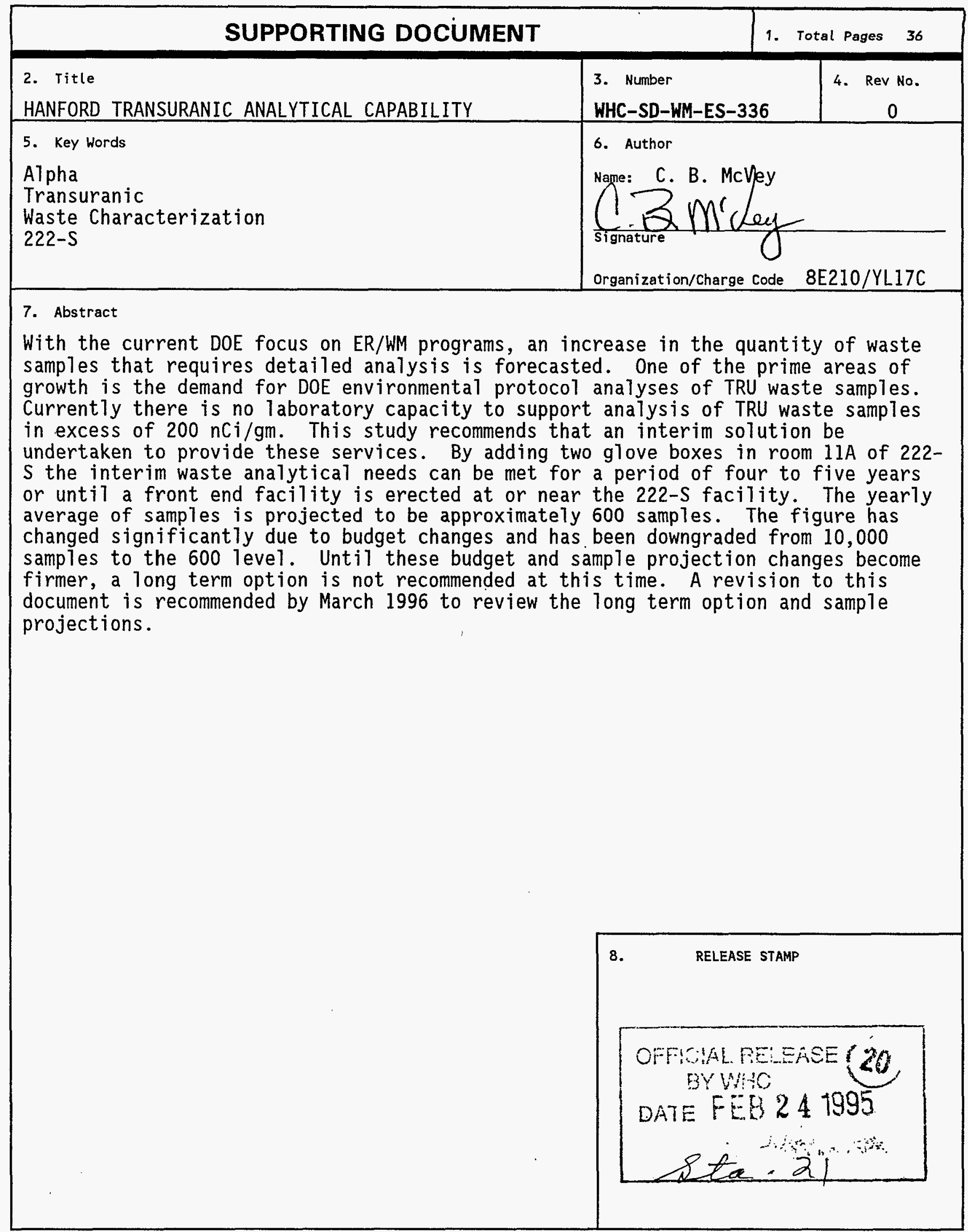


ENGINEERING STUDY

\title{
HANFORD TRANSURANIC ANALYTICAL CAPABILITY
}

\section{Issued by:}

\author{
Hanford Analytical Services \\ Program Integration \\ Westinghouse Hanford Company \\ Richland, Washington
}

March 1995
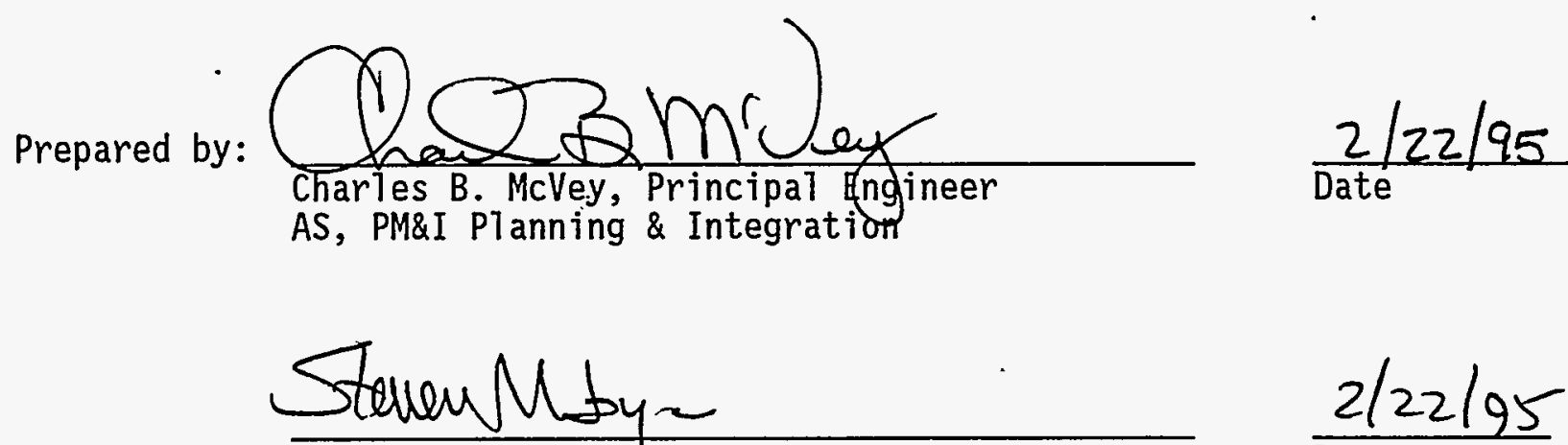

S. M. Joyce, Manager

AS, PM\&I Planning \& Integration
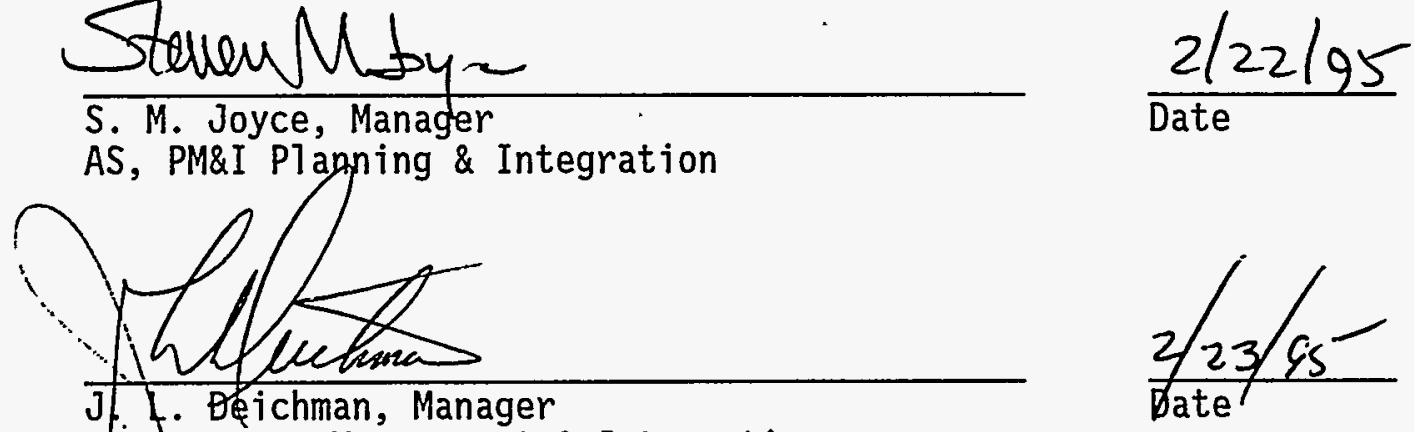

$A \dot{5}$, Program Management \& Integration
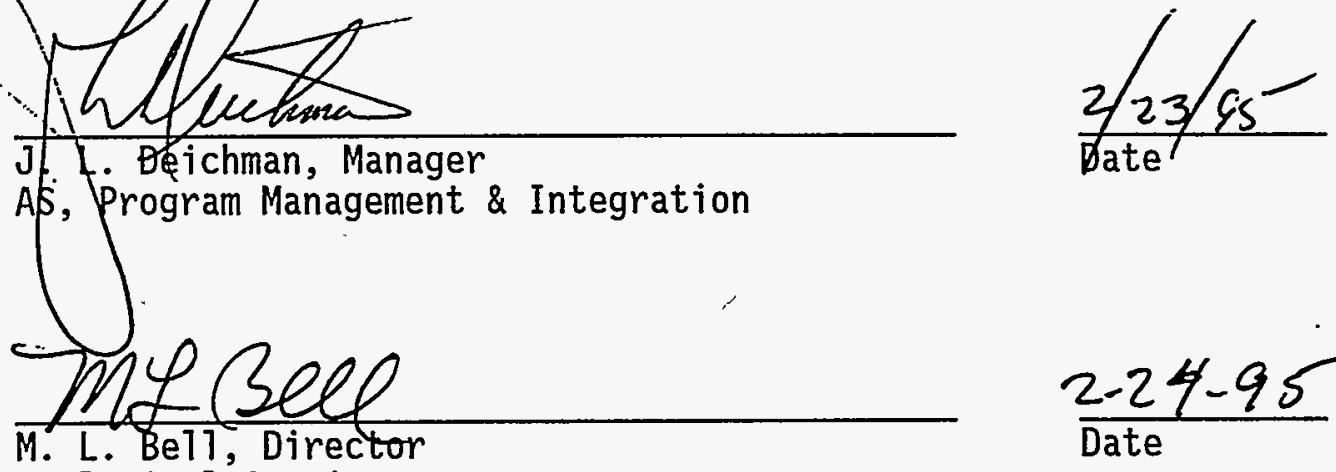

Analytical Services

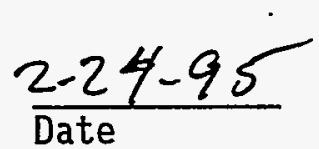




\section{WHC-SD-HM-ES-336 REV 0}

TABLE OF CONTENTS

1.0 OBJECTIVE . . . . . . . . . . . . . . . . . . . 4

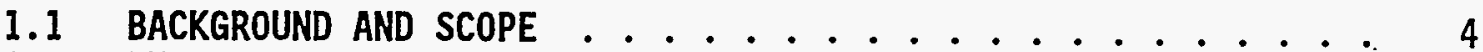

1.2 PURPOSE AND NEED ...................... 4

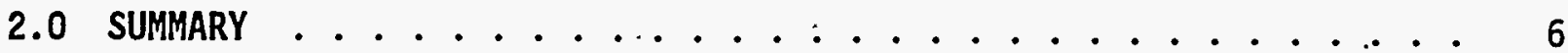

3.0 RECOMMENDATIONS AND CONCLUSIONS . . . . . . . . . . . . . 8

3.1 RECOMMENDATIONS ................... 8

3.2 CONCLUSIONS . . . . . . . . . . . . . . . . 8

4.0 UNCERTAINTIES . . . . . . . . . . . . . . . . . 10

5.0 DESCRIPTION OF ALTERNATIVES AND SOLUTIONS AND SOLUTIONS . . . . . 11

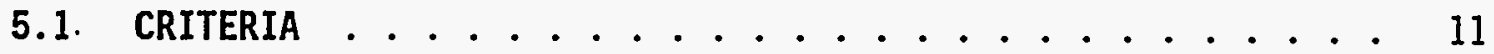

5.1.1 Building Requirements .............. 11

5.1.2 Operating Cost .................... 13

5.1.3 Construction Cost ................ 13

5.1.4 Safety .................... 13

5.1.5 Schedule ................... 13

5.2 ASSUMPTIONS . . . . . . . . . . . . . . 15

5.2.1 TRU Haste Volume and Location ............ 15

5.2.2 TRU Waste Generator Regulatory Commitments . . . . . . 16

5.2.3 Current TRU and TRU-Mixed Waste Disposal and

Transportation Needs. ............ 17

5.2.4 Facility Design Bases . . . . . . . . . . . . . . 17

5.2.5 Sample Packaging and Transportation ........ 18

5.2.5.1 Payloads and Quantities. . . . . . . . 18

5.2.6 Laboratory Safety Assessment . . . . . . . . . 19

5.2.7 Facility Hazard Classification . . . . . . . . . . 19

5.2.8 Facility Process Safety ............. 20

5.2.9 Transportation Risk .............. 20

5.2.10 Nuclear Criticality Safety ............ 21

5.2.11 External Events ................. 21

5.2.12 NEPA Requirements ................. 21

5.2.13 Radioactive Haste Management . . . . . . . . . 21

5.2.14 Safeguards and Security ............. 22

5.2.15 Quality Assurance ............... 22

5.2.16 Turnaround Time ................. 22

5.2.17 Material Storage and Transport Systems . . . . . . . 22

5.2.18 Site Waste Processing Support Requirements . . . . . 23

5.3 ALTERNATIVES . . . . . . . . . . . . . . . . . . 23

5.3.1 Offsite Laboratories (LITCO, LANL, Argonne East) . . . 23

5.3.2 Hanford ................... . 23 
WHC-SD-WM-ES-336 REV 0

5.3.2.1 Fuels and Materials Examination Facility

(FMEF) ............... 23

5.3.2.2 Plutonium Finishing Plant (PFP) . . . . . . . 24

5.3.2.3 231-Z .................. 24

5.3.2.4 Plutonium Uranium Extraction Facility

5.3 .2 .5 (PUREX) . . . . . . . . . . . 24

5.3 .2 .6 Uo

5.3.2.7 325 Building $\cdot \cdot \cdot \cdot \cdot \cdot \cdot \cdot \cdot \cdot \cdot \cdot \cdot \cdot \cdot \cdot{ }_{26}$

5.3.2.8 222-s Complex................. 26

5.3.2.9 New Facility .............. 27

5.3.2.10 Outsourcing ............. 27

6.0 DISCUSSION OF PREFERRED ALTERNATIVE/SOLUTION . . . . . . . . 29

7.0 NO ACTION ALTERNATIVE . . . . . . . . . . . . . 31

8.0 REFERENCES . . . . . . . . . . . . . . . 32

9.0 APPENDIXES $\ldots \ldots \ldots \ldots \ldots \ldots$ 


\section{HANFORD TRANSURANIC ANALYTICAL CAPABILITY ENGINEERING STUDY}

\subsection{OBJECTIVE}

\subsection{BACKGROUND AND SCOPE}

Existing Department of Energy (DOE) Hanford Site analytical laboratories do not currently have the capability or capacity to meet the DOE Environmental Restoration and Waste Management (ER/WM) environmental protocol needs for analysis of transuranic (TRU) waste. TRU waste is radioactive waste contaminated with alpha emitting transuranium radionuclides with half-lives greater that 20 years and concentrations greater than 100 nano-curies per gram $(n \mathrm{C} i / g)$. In this document, TRU mixed waste, which includes non-radioactive, hazardous constituents in addition to TRU radionuclides, is considered to be a subgroup of TRU waste. As DOE site cleanup strategies and Waste Isolation Pilot Plant (WIPP) analytical needs are further defined, additional sample analysis requirements will be developed.

\subsection{PURPOSE AND NEED}

With the current DOE focus on ER/WM programs at DOE nuclear waste generator sites, a significant increase in the quantity of waste samples that require detailed analysis is forecast. One of the key areas of growth is the demand for DOE environmental protocol analyses of TRU waste samples. These analyses include, but may not be 1 imited to, protocols required by regulatory agencies with the main driver being the Resource Conservation and Recovery Act (RCRA). Analys is of TRU waste samples is required for characterization, retrieval, treatment, environmental restoration and solid waste generation prior to the transfer and placement of wastes for permanent disposal at the WIPP. The WIPP Waste Acceptance Criteria require that various constituents of the waste be known in order to assure proper and safe disposal. This project supports the Solid Waste program which includes the Tri-Party Agreement Milestone M-18-00, Complete Waste Receiving and Processing (WRAP) Module I construction and initiate operations by 1997.

Hanford has developed a strategy for providing analytical services to the site cleanup mission. The strategy as originaliy developed utilized a combination of on-site, commercial and other DOE analytical 1aboratories. As the Solid Waste Program evolved, the requirements for transuranic sample analyses became better defined. A strategy for providing analytical services to support this transuranic sample load was subsequently developed. Low activity (less than $200 \mathrm{nCi} / \mathrm{g}$ ) samples can be analyzed commercially at onsite analytical laboratories. These samples are not considered as part of this study since they can be done with existing facility capabilities. The higher activity samples, some with significant levels of beta and gamma contamination, present a far more difficult challenge. Existing Hanford Site analytical laboratories do not currently have the capability or capacity to meet the protocol needs for analys is of TRU waste greater than 200 nanocuries/gram. 


\section{WHC-SD-WM-ES-336 REV 0}

When Hanford and other sites compiled the needs for high level transuranic sample analysis, it was apparent that a significant shortfall in analytical capacity existed across the DOE complex and across the commercial sector. Very limited capacity is available at Hanford, Los Alamos and Argonne East for providing environmental analyses on these types of samples. DOE-HQ developed a strategy for constructing regional transuranic laboratories at selected DOE sites to address this problem. These regional laboratories, mainly because of the large cost (greater than $\$ 300 \mathrm{M}$ ) and the uncertainty of the site sample projections, have not been supported. Hanford requires this capability to support the Solid Waste Program. This study of facility requirements at Hanford will investigate what is necessary to analyze these high activity transuranic samples and make recommendations for the interim period and for a final resolution.

The function of a transuranic analytical facility is to provide capability to perform all DOE environmental protocol analys is required for TRU mixed waste samples prior to waste characterization, retrieval, treatment, reduction and storage of that waste. The facility is planned to have the analytical capacity to handle approximately 8,500 samples per year after the year 2002. WRAP 1 sample needs are 3,000 samples per year with the balance derived from decontamination and decommissioning, TRU-waste retrieval, environmental restoration and solid waste generation programs. For site characterization needs, a forecast of 800 samples per year in 2002 will vary based on higher activity drum processing (Reference 17). 


\subsection{SUMMARY}

A transuranic analytical facility will provide the capability for full DOE environmental protocol and RCRA analysis of transuranic (TRU) mixed waste samples. Characterization of these samples is required by DOE environmental cleanup program as explained by the ER/WM Five-Year Plan (Ref. 4). This addresses only one part of the cleanup program analytical requirements; it does not address other types of waste such as high level waste, low level waste, etc., or TRU mixed waste that contains low enough concentrations of alpha activity to be analyzed in beta/gamma laboratories. The inventory limits of the facility selected for interim, and eventually long term, must be investigated to insure that these limits are not exceeded or that the production of the laboratory will not be impacted.

The function of a transuranic analytical facility is to provide full routine analytical capability within one laboratory. It is also to perform any and a11 DOE environmental protocol and RCRA analysis required for TRU mixed waste samples prior to waste treatment, reduction and storage of that waste. Analytical work will be routine and not development in nature. Development work will be minimal and only for procedures for sample preparation development. To meet the immediate needs (FY-1997) for analysis of TRU mixed waste samples, an interim solution is required. The interim solution will provide analytical capability from FY 1997 until a permanent facility is operational in FY. 2001 or later. Several options were considered. These included PUREX, T-P1ant, PFP, PNL's 325 laboratory, and the 222-S laboratory. These options were evaluated against each other utilizing their known advantages and disadvantages. The 325 and PFP options were inadequately supported and the information gathered was 1 imited. A recommendation to use the 222-S Laboratory for the interim use and a separate recommendation for the long term use are further described below:

\section{Interim}

The 222-S laboratory option emerged as the primary selection due to its location, ability to meet FY 1997 needs and capability to accommodate equipment and instrumentation. This eliminates additional transportation risks due to its location at an existing laboratory. The samples would be prepared in glove boxes located in the hot cell addition at 222-S and then moved to the appropriate laboratory room for analysis. Space is available within the 222-S hot cell room in the location next to the anteroom south of the west bank of analytical cells. Another advantage is that analytical cells are close by to allow remote handling of TRU waste that may exceed.glove box. limits. The operational burden for operation of these glove boxes would be part of the normal operational burden for 222-S facility. Personnel are presently located at the facility and additional personnel would not be required. Existing waste handling operations would be utilized for the proper handling and packaging of waste generated by this operation. All utilities are available for this operation, but would require redesign for connection to the new boxes.

The interim option requires space for three glove boxes for sufficient operational capacity of TRU samples. The hot cell room has space for only two glove boxes without interference with normal daily operations. Additional glove box requirements may be alleviated with shift work when sample load warrants additional effort. Space within the 222-S facility may become 


\section{WHC-SD-HM-ES-336 REV 0}

available at a later date as operational experience is gained and sample flows are stabilized. This option may evolve into the permanent location if appropriate space can be assigned. Operational costs may be impacted by the limit of two glove boxes.

This option requires an estimated investment of approximately $\$ 1,000,000$ to design ventilation connections from existing system to glove boxes, installation and testing of glove boxes and appropriate procedures being placed in service. The possibility of the glove boxes being obtained from the Fuels Materials and Examination Facility (FMEF) excess is very high and should be pursued. Further investigations of equipment layout and costs is required for an improved estimate on this option.

\section{Long Term}

The long term option selected is to place a separate front end facility at the 222-S facility as the demand requires. This facility would provide sufficient space for separation of waste samples for analytical analysis prior to them being allowed to enter the 222-S facility. This option requires line Item funding of approximately $\$ 5,000,000$. However, due to the questionable sample forecasts, this long term option should not be pursued until these projections are clarified. The sample projections started at 10,000 sample per year when this engineering study began and has undergone numerous reductions to approximately 600 samples per year. This significant reduction has impacted the progress of this engineering study and until these projections become stable, the long term option should be deferred. 


\subsection{RECOMMENDATIONS AND CONCLUSIONS}

The recommendation of this study provides resolutions for two separate time periods. An interim recommendation provides services for TRU analytical needs as early as FY 1997. This option would continue to provide services until a long term recommendation is in operation. These recommendations are discussed below.

\subsection{RECOMMENDATIONS}

It is the recommendation of this engineering study that an interim solution which provides separation capabilities of TRU mixed waste samples be provided by September 1997. To meet this aggressive schedule the 222-S hot ce17. facility option was selected. Actions should be undertaken to secure two glove boxes from Fuels and Materials Examination Facility (FMEF), or similar, as soon as reasonable. These glove boxes should be delivered to the 222-S facility and stored until installation. The space at the 222-S hot cell room should be identified and design started for ventilation and electrical modifications for the acquired glove boxes. Procedures needed for operation and testing of these glove boxes should be written prior to completion of the installation to support the schedule for being operational by September 1997 .

The recommendation for the long term option is not to proceed with the selected alternative until the budgets and the sample projections stabilize. Since the inception of this engineering study the Hanford Site budget has incurred significant reductions. As a result of these budget changes the sample projections have become very questionable. The sample projections have changed from 10,000 samples per year to approximately 600 samples per year (Reference 17). Further budget reductions may impact the sample projections as we1l. Once the budget and sample projections stabilize, the long term option should be re-evaluated with the information available at the time.

The recommendation for a long term solution is to seek Line Item funding to build a separate front end separation facility near the 222-S facility. The new facility would provide sufficient space for sample preparation, sample storage, waste handling, change rooms, chemical supplies, offices, equipment and sample decontamination. The facility should be placed as close as allowable to the 222-S facility to allow transfer of samples from the preparation area to the laboratory area without requiring special packaging for shipment.

\subsection{CONCLUSIONS}

Based on analytical needs at the Hanford Site and the Tack of capability a facility is required to provide support for TRU mixed waste analysis. An interim solution is required to meet the immediate needs of the solid waste program at WRAP in FY 1997. Due to the uncertainties with the budget and sample projections a long term option is not supported at this time.

The location of the interim selection was evaluated against several alternatives (T-Plant, PUREX, PFP, 222-S and 325 Building) and weighted criteria from section 5.1. A team evaluated the recommendations and prioritized them using a weighted criteria process. The results of this process are included in Appendix A. As a result of this process the 222-S hot 


\section{WHC-SD-WM-ES-336 REV 0}

cell room modifications was selected as the preferred alternative. This was due to reduced transportation risk, ability to meet the aggressive schedule, reduced operational cost, improved safety capability and low implementation costs.

As a long term solution the 325 laboratory was a close contender, but was not selected. With the goal established by "site principals", to remove nuclear material from the 300 Area, it appears contradictory to introduce another nuclear function. This facility should be re-evaluated at the time this engineering study is revised. 


\section{WHC-SD-HM-ES-336 REV 0}

\subsection{UNCERTAINTIES}

Future mission changes at the Hanford site remain uncertain. Past history has revealed that mission changes have impacted the utilization of Hanford facilities. Presently with the cTeanup scope for the Hanford site, several facilities have been identified for accelerated decontamination and decommissioning which leaves these buildings unavailable for future use.

Funding impacts due to budget reductions are present in the $p l a n n i n g$ of the Hanford mission. Reductions have been significant and have affected several major programs and projects. This uncertainty is projected to continue. Major expenditures for projects will be under close scrutiny because of these budget pressures.

Regulatory changes may impact transportation requirements for transuranic samples from the source to the laboratory destination. Transportation across public highways will remain a constant concern in the public eye as to the safety of the packaging and of the vehicle. Changes to the regulations governing this type of transportation may cause significant impacts. The transportation on the Hanford site also is a concern for regulatory changes as the site continues to change. These changes may require tighter restrictions as to movement of transuranic samples from the source to a laboratory or may require greater restrictions for packaging.

The sampling schedule that was used for the development of this study is in continuous development and may not have valid assumptions for future years. During the preparation of this study, a major impact to the Waste Receiving and Packaging project affected the total number of samples for transuranic analysis. Further impacts may be realized due to the funding changes that programs may encounter in the future. These impacts may affect favorably or unfavorably the sample projection for the Transuranic Analytical Laboratory. The latest information was utilized during preparation of this study.

The options for interim and long term involve integration with existing facilities, the only exception is a new separate facility. This integration consist of using existing services such as electrical, steam, water and waste disposal systems. The burden (cost) for these services may be assessed against the option for a portion of the total facility or possibly the entire facility operating cost. This uncertainty shall be defined when an alternative is selected and further discussions with the affected facility is undertaken.

The impact of the NEPA process and pubTic acceptance, both scheduTe and cost, cannot be forecasted at this time. Each alternative may require a different process and will have to be evaluated on an individual basis. 
WHC-SD-WM-ES-336 REV 0

\subsection{DESCRIPTION OF ALTERNATIVES AND SOLUTIONS}

\subsection{CRITERIA}

All alternatives discussed in the following sections were evaluated against five criteria. These criteria were selected due to their relative importance for the operation of programs for transuranic waste analysis and packaging. The proper analysis of transuranic waste is required by the Waste Isolation Pilot Plant (WIPP) and the Department of Transportation (DOT) prior to shipment. The criteria were assigned a weighted value based on their relative significance to one another. These weight factors are shown in the section headings as Interim and Long Term.

The alternatives were independently evaluated against the criteria by the author and then evaluated by a management team for the interim and long term conditions. The independent evaluation was not made available to the management team for their analysis. All alternatives were then totaled and reviewed to select potential recommendations and/or combination of alternatives for recommendations. Table 5.1 contains the interim alternatives and Table 5.2 has the long term alternatives.

The selection criteria is used to evaluate an interim and a long term solution. The interim evaluation will look at a "head end" concept where a separation process can be done and the remaining sample can be shipped to a laboratory for analysis. This concept will allow the use of existing facilities which can be modified to accommodate the requirements for separation of alpha and gamma contaminants from the sample. A long term resolution will evaluate using existing facilities, new additions to existing facilities and a new facility using these same criteria. An interim resolution may qualify as being acceptable for the long term recommendation as wel1.

\subsubsection{Building Requirements (Interim = 7, Long Term = 5)}

A transuranic analytical facility minimum building requirements consists of a sample receiving area, sample preparation room, sample storage room, general offices, health physics technician office, mechanical room, chemical supply room, solid and hazardous waste handling facility, instrument repair, equipment and sample decontamination facility, air locks and change rooms. Other operational and support facilities are to be provided by other established functional facilities, if required. For the interim option the minimum space required is approximately $600 \mathrm{~m}^{2}\left(6,500 \mathrm{ft}^{2}\right)$ for laboratory functions. While for the long term option this are should be approximately $1,100 \mathrm{~m}^{2}\left(12,000 \mathrm{ft}^{2}\right)$.

A sample receiving area with storage shelving for samples and an air lock access to the sample preparation area is required. Samples are estimated to be contained in one liter bottles for sizing of the storage area. All samples will not be received in one 7 iter bottles, but this is used as the worst possible case for sizing. Laboratory Information Management System (LIMS) service will be required for the logging in and tracking of samples as they are processed to maintain "chain-of-custody" documentation. 


\section{WHC-SD-WH-ES-336 REV 0}

The sample preparation room must have the capability to contain six glove boxes for the separation and sample preparation of transuranic samples greater than $200 \mathrm{nCi} / \mathrm{g}$. The glove boxes are to be 1.2 meters (m) by $3.7 \mathrm{~m}$. The room must have the capability to accommodate casework, gloveboxes and computers.

A sample storage room is required for the protection of sample containers while samples are in process. The area must be capable of handling a two months capacity. One months capacity is estimated to be approximately 600 samples. Sample separation is required for in-process samples and newly recejved samples.

The described building requirements provide an estimated space criteria as shown in Table 1 below.

Table 1 - Estimated Space Criteria

\begin{tabular}{|c|c|c|}
\hline ROOM DESCRIPTION & AREA (SQUARE METERS)* & ADDITIONAL INFORMATION \\
\hline Sample. Receiving Area & 30 & $\begin{array}{l}\text { Storage shelving for } \\
\text { samples }\end{array}$ \\
\hline Sample .Storage & 60 & $\begin{array}{l}\text { Shielding may be } \\
\text { required, space for } \\
\text { receiving and in- } \\
\text { process }\end{array}$ \\
\hline Sample Preparation & 250 & $\begin{array}{l}6 \text { gloveboxes, case work } \\
\text { and computers }\end{array}$ \\
\hline Change Rooms & 30 & Men's and Women's \\
\hline General Offices & 60 & Four \\
\hline HPT Office & 15 & One \\
\hline Chemical and Supply & 30 & Shelving \\
\hline $\begin{array}{l}\text { Solid and Hazardous } \\
\text { Waste Handling }\end{array}$ & 50 & $\begin{array}{l}\text { Tables, Drum Storage, } \\
\text { supplies, and computers }\end{array}$ \\
\hline Instrument Repair & 15 & Benches \\
\hline $\begin{array}{l}\text { Equipment and Sample } \\
\text { Decontamination }\end{array}$ & 10 & GTove box \\
\hline Air Locks & 15 & Two required \\
\hline TOTAL & 565 & - \\
\hline
\end{tabular}

* Room areas are rough estimation and used for cost comparisons only.

The facility will require the capability to meet changes in production levels and missions. The facility must be. able to provide services to the Hanford site for the 1 ife of the cleanup mission for transuranic waste. A 10 will represent a building which meets a 71 requirements and a 0 will represent a building with the most restrictions. 


\subsubsection{Operating Cost (Interim $=$ 9, Long Term $=9$ )}

Operational costs are driven by staffing, transportation of samples, and facility costs. Staffing will be affected by site location. If the facility can be located near an existing laboratory, some staff positions can be shared. Transportation costs is also affected by site location. The further the facility is located from an analytical laboratory the higher the cost for transporting samples. Facility costs are higher for a standalone facility versus a facility that can share utilities. A 10 rating will represent a low operational cost and a 0 will represent the highest operational cost.

\subsubsection{Construction Cost (Interim $=8$, Long Term $=6$ )}

This is the cost for modifications or construction to implement the action recommended. The cost will include expense and/or capital funds, depending on the alternative. Cost drivers are construction of new facilities, and modification to existing facilities. A 10 represents a 10 w cost and a 0 will represent a high cost.

\subsubsection{Safety (Interim $=10$, Long Term $=10$ )}

The safe operations of each alternative is assigned the greatest value to maintain safety for personnel, environment and operations. The safe handling of transuranic waste samples is required for the protection of the workers and the public. Improvement of existing conditions required for alternatives to meet the safety requirements for handling, shipping, packaging of transuranic waste and required site safety documentation (SAR, NEPA, SARP, Operating Procedures, and compliance with regulations). Impacts on existing safety documentation is evaluated on an case by case basis. A value of 10 represents the least required improvement of safety and a 0 wi11 represent the greatest required improvement of safety.

\subsubsection{Schedule (Interim $=8$, Long Term $=5$ )}

The facility must be operational by FY 1997 in order to support the Waste Receiving and Packaging facility shipments to WIPP. This schedule is not attainable for capital projects due to time restraints for funding. Therefore an interim solution will be required to handle the transuranic samples for characterization from present until an option is available for operation. Consideration will be given to alternatives that can fulfil the interim and permanent requirements. A value of 10 represents the earliest completion possible and a 0 represents the latest completion. 
WHC-SD-WM-ES-336 REV 0

Table 5.1

ALTERNATIVE SELECTION - INTERIM

\begin{tabular}{|c|c|c|c|c|c|c||}
\hline Weight & 7 & 9 & 8 & 10 & 8 & \\
\hline \hline Category & Build. Req. & Operation & Construct. & Safety & Sched & TOTAL \\
\hline \hline Plutonium Finishing Plant & $7 / 49$ & $5 / 45$ & $7 / 56$ & $5 / 50$ & $2 / 16$ & 216 \\
\hline T-P1ant Head End Facility & $4 / 28$ & $6 / 54$ & $4 / 32$ & $6 / 60$ & $1 / 8$ & 188 \\
\hline PUREX & $6 / 42$ & $5 / 45$ & $4 / 32$ & $7 / 70$ & $1 / 8$ & 197 \\
\hline 325 Building & $9 / 63$ & $7 / 63$ & $8 / 64$ & $8 / 80$ & $6 / 48$ & 318 \\
\hline $222-S$ Hot Cell Facility & $7 / 49$ & $7 / 63$ & $8 / 64$ & $8 / 80$ & $8 / 64$ & 329 \\
\hline
\end{tabular}

Table 5.2

ALTERNATIVE SELECTION - LONG TERM

\begin{tabular}{|c|c|c|c|c|c|c|}
\hline Weight & 5 & 9 & 6 & 10 & 5 & \\
\hline Category & Build Req. & Operation & Construct & Safety & Schedule & TOTAL \\
\hline $\begin{array}{l}\text { Plutonium Finishing } \\
\text { Plant (Head End) }\end{array}$ & $6 / 30$ & $3 / 27$ & $5 / 30$ & $7 / 70$ & $7 / 35$ & 192 \\
\hline PUREX (Head End) & $3 / 15$ & $5 / 45$ & $1 / 24$ & $7 / 70$ & $5 / 25$ & 179 \\
\hline 325 Building (Head End) & $8 / 40$ & $4 / 36$ & $9 / 54$ & $8 / 80$ & $4 / 20$ & 230 \\
\hline 222-S Addition (Head End) & $10 / 50$ & $9 / 81$ & $6 / 36$ & $\therefore 9 / 90$ & $9 / 45$ & $302^{3}$ \\
\hline $\begin{array}{l}\text { Plutonium Finishing } \\
\text { Plant (Head End \& Lab) }\end{array}$ & $4 / 20$ & $3 / 27$ & $5 / 30$ & $7 / 70$ & $6 / 30$ & 177 \\
\hline $\begin{array}{l}325 \text { Building } \\
\text { (Head End \& Lab) }\end{array}$ & $8 / 40$ & $8 / 72$ & $9 / 54$ & $8 / 80$ & $9 / 45$ & 291 \\
\hline $\begin{array}{l}\text { New Facility } \\
\text { (Head End \& Lab) }\end{array}$ & $10 / 50$ & $9 / 81$ & $1 / 6$ & $9 / 90$ & $5 / 25$ & 252 \\
\hline
\end{tabular}




\section{WHC-SD-WM-ES-336 REV 0}

\subsection{ASSUMPTIONS}

The relative sampling needs for Hanford are proportional to the total volume of TRU waste buried onsite.

Net sample weight will generally be 500 grams or less, with the majority of the sample weight being the contaminated article itself (like laboratory glassware, gloves, etc.). When fully operational, the total number of samples shipped will be approximately 600 samples per year. Up to 10 to 15 samples per day may be shipped. For purposes of this engineering study each sample is assumed to be $5,000 \mathrm{nCi} / \mathrm{g}$ for the high end of the activity level and $100 \mathrm{nCi} / \mathrm{g}$ for the low end. At any time a spike may occur from a sample received and this is estimated to be a factor of 10 higher. Using these assumptions the range of inventory for a three month period will be $8 \times 10^{-4}$ to $3.75 \times 10^{-2}$ curies and $8 \times 10^{-3}$ to $3.75 \times 10^{-1}$ curies for a spike.

The facility will operate for the full period of the clean-up mission at the Hanford site. The facility is to be operated at the hazard classification of the facility selected.

\subsubsection{TRU Waste Volume and Location}

The Hanford Site, located in Southeastern Washington State, covers 1450 $\mathrm{m}^{2}$ (560 square miles). There have been various activities at this site since 1943. Some of the Nation's earliest nuclear reactors and nuclear fuels reprocessing facilities are located at this site. The Hanford Site's missions have included plutonium separation, waste management, environmental restoration, advanced reactor design and testing, basic scientific research, and renewable energy technologies development. The Site is in an arid location, with the largest fraction of the waste sites in the central plateau area well away. from the Columbia River. About 340,000 people reside within a $80.5-k i l o m e t e r(\mathrm{~km})$ radius of the center of the Site (1980 U.S. census).

For more than 40 years, DOE and its predecessors, the Atomic Energy Commission (AEC) and Energy Development and Research Agency (EDRA) have had the responsibility to design, develop, test, and produce nuclear weapons for defense. These defense activities have created waste by-products known as transuranic, or TRU wastes. Transuranic (TRU) waste is contaminated with alpha-emitting radionuclides having atomic numbers greater than 92 and half-lives greater than 20 years, in concentrations greater than $100 \mathrm{nCi} / \mathrm{g}$ of waste at the time of assay. This material results primarily from the reprocessing of plutonium bearing reactor fuel. Many TRU wastes consist of everyday items used by workers at the defense facility. Items such as rubber gloves, shoe covers, cloth lab coats, plastic bags, laboratory glass, and rags become contaminated in routine operations. When these items are discarded, they become TRU mixed waste.

Prior to 1970, all TRU contaminated waste was buried at several Hanford sites in pits and trenches, and covered with soil. In 1970, the federal government concluded that TRU wastes should have greater confinement from the environment. Consequently, since 1970 these wastes have been stored so they can be easily retrieved. Although a few daughter products have energetic gamma emissions, most of this waste can be handled with the shielding that is provided by the waste package and is classified as "contact-handled" TRU waste. Only about $2-4 \%$ of the retrievable stored, TRU contaminated waste 
contains enough beta, gamma, and neutron emitters (more than $200 \mathrm{mrem} / \mathrm{h}$ ) to require remote handling; this waste is designated as "remote-handled" TRU waste.

Over the years, some of the buried waste containers have decayed and been breached, contaminating the surrounding soil. Also, in the early days at Hanford, some liquid waste that contained TRU elements was spilled on, or drained to, the earth. The volume of contaminated soil and the mass of TRU elements in the soil is very difficult to estimate.

Waste Isolation Pilot Project (WIPP)

The Waste Isolation Pilot Plant is a research and development facility of the United States Department of Energy that is designated to demonstrate the safe disposal of defense-generated radioactive waste. The WIPP site includes both surface and underground structures on 4,217 hectares (ha) $(10,420$ acres) in a remote area 42 meters (26 miles) east of Carlsbad, in southeastern New Mexico.

The WIPP site will primarily demonstrate the safe disposal of defense-generated transuranic wastes. These will arrive from other DOE sites in two forms:

Contact-handled TRU are contained in metal drums or boxes in specially designed shipping.containers. The radiation level on the outside of the drums and boxes is low enough $(<200 \mathrm{mR} / \mathrm{hr}$ ) that they can be safely managed in a hands-on manner. After arrival at the WIPP site, the shipping containers will be inspected, then the contents will be removed, inspected, and placed on pallets before being lowered underground to be placed in storage:

Remote-handled TRU will have high enough radiation levels (>200mR/hr) at the surface of their containers that they will require handling by remotely. controlled equipment for maximum protection to workers. These wastes will be housed in shielded shipping casks transported by truck. The casks will be opened in the WIPP Waste Handling Building's shielded hot cell by the use of large manipulators, cranes, and grapples. The actual waste canisters will be remotely surveyed for surface contamination, inspected, and transferred into a special shielded cask designed to move the RH TRU waste between surface and underground facilities at the WIPP. Underground cask transporters and emplacement machines will transfer the casks to horizontally drilled bore holes in the salt storage areas.

\subsubsection{TRU Haste Generator Regulatory Commitments}

\section{Regulatory Commitments}

Tri-Party Agreement (Hanford Federal Facility Agreement and Consent Order) recently finalized among DOE, EPA, and the State of Washington Department of Ecology.

RCRA - As implemented through State of Washington Dangerous Waste Regutations. 


\section{WHC-SD-WM-ES-336 REV 0}

CERCLA - Significant anaTytical support will be required to support new Hanford environmental cleanup activities, both in terms of analysis types and quantity of samples in the near future. Three new areas are:

Major Part B activities include grout and double shell tank farms.

Major Closure Plans include single shell tanks.

The EPA and State of Washington have indirectly allowed current Hanford Environmental Compliance activities to continue without the ability to perform protocol analyses. Enforcement of compliance to analytical protocols and state regulatory certification of laboratories is anticipated in the next few years. Hanford Environmental Program activities remain vulnerable to challenge until recommended analytical laboratory upgrades are completed.

\subsubsection{Current TRU and TRU-Mixed Waste Disposal and Transportation Needs.}

Waste generated after 1970 was stored pending final disposal at the Waste Isolation Pilot Plant (WIPP). TRU wastes buried prior to 1970 are considered disposed and are not candidates for retrieval unless site remediation under the CERCLA program requires removal. Most of the waste discussed in this study will be sent to WIPP. Repackaging of waste will be required prior to disposal at WIPP.

Hanford predicts the generation of over $10,000 \mathrm{~m}^{3}$ due primarily to cleanup activities such as HWVP, PUREX, 233S, 2322 and Single Shell Tank facility closures.

Most of the newly generated waste will probably be packaged in 208 liters (1) (55-gallon) drums. Hanford al so predicts the generation of standard waste boxes and a small amount of other, non-specified packages. The facility will become a generator of new waste. These wastes are projected in Appendix B.

\subsubsection{Facility Design Bases}

As a long term solution the facility will be designed and built as a partial capability laboratory, for the breakdown and sample preparation of transuranic (TRU) mixed waste samples. The capability to prepare samples and standards on TRU mixed wastes and their chemical constituents will be required. The facility will treat all wastes generated by these activities for disposal according to all state, federal, and DOE regulations. Solid waste generation is estimated to be $1,000 \mathrm{Kg}$ per year and Tiquid waste is estimated at 7,300 liters per year. Further analyses that will be performed in other facilities include radiological determinations as well as EPA required analyses as specified in SW-846, Contract Laboratory Program statements of work, and other environmental regulations.

In addition, areas will be provided to treat generated liquid wastes. LIMS will be utilized within the facility for sample management, accountability and laboratory facility monitoring. State of the art laboratory automation systems should be planned where appropriate to minimize long-term analytical costs, while improving process control. 
The design of the facility will accommodate future growth by providing expansion capability as required by DOE Order 6430.1A, "General Design Criteria."

The facility will include approximately $557 \mathrm{~m}^{2}\left(6,000 \mathrm{ft}^{2}\right)$, including about $325 \mathrm{~m}^{2}\left(3,500 \mathrm{ft}^{2}\right)$ of 1 aboratory building space and

$232 \mathrm{~m}^{2}\left(2,500 \mathrm{ft}^{2}\right)$ of connected laboratory support and office space.

Capability to handle at least 600 full RCRA analysis per year with future expansion capacity is required. Expansion capacity will be dependent on future sample projection growth.

\subsubsection{Sample Packaging and Transportation}

The fundamental criteria for the packaging and transportation of hazardous materials such as TRU samples are found in the DOE Orders. These Orders typically impose the regulatory requirements of Titles 10 (Nuclear Regulatory Commission) and 49 (Department of Transportation) of the Code of Federal Regulations (CFR). Certain State, EPA, and OSHA requirements also apply. The following is a summary of the appropriate hierarchy of the primary criteria for packaging and transportation.

\subsubsection{Payloads and Quantities.}

Three hazardous material categories are identified: process materials, waste, and the TRU samples. The majority of this discussion will be with regard to the TRU sampies. Process materials (i.e., laboratory reagents, acids, bases) will not be addressed in this study. These materials will be packaged and transported in accordance with DOT regulations, and should not present any unusual industrial or regulatory issues. Outgoing TRU waste will ultimately be transported to WIPP in a solid form, either from the generator site or the new facility itself. The waste will be loaded in 208 liter (55-gal) drums and Standard Waste Boxes (SWB), and overpacked in the TRUPACT-II Type B quantity packaging. Other (non-TRU) radioactive and other hazardous waste may be in solid or liquid form (absorbed), and will likely be packaged in contact handled Type A quantity 208 Titer (55-ga7) drums. At this time, the quantities of outgoing waste and the logistical scenarios for its movement are unknown.

It is assumed that net sample weight wiil generally be 500 grams or less, with the majority of the sample weight being the contaminated article itseif. Up to 15 samples per day may be shipped.

To select the proper packaging for the transport of radioactive material, the payload must be adequately characterized in terms of radionuclide, quantity, chemical form, and physical form. Sample radionuclide components will primarily include isotopes of uranium, plutonium and americium, other TRU, etc. Under circumstances associated with shipping radioactive material products, precise characterization of the payload must be established for shipping documentation and packaging choice. For the case of radioactive and other hazardous material samples, a best approximation of the constituents is sufficient, as implied by 49 CFR 172.101(c)(12): 
"A material for which the hazard class is to be determined by testing or a material that is a hazardous waste may be assigned a tentative shipping name, hazard class and identification number, based on the shipper's tentative determination according to:

(i) Defining criteria in this subchapter;

(ii) The hazard precedence prescribed in 173.2 of this subchapter; and

(iii) The shipper's knowledge of the material."

TRU sample characterization for packaging and shipping will rely on process knowledge, sample results from similar waste streams, historical data, and direct radiation readings.

TRU samples to and from the facility may be solids, liquids, or gases. Solids (including absorbed liquids) comprise the majority of the samples. Typical7y, the sample will consist of an innocuous article (glove, bottle, wipes, etc.) contaminated with TRU radionuclides. As the overall quantities of gas samples throughout the DOE complex is expected to be very low (as compared to solids and liquids), gases will be disregarded for this study. Chemical form will vary. The majority of samples will either be radioactive with no other hazards, or will include combustibles as a secondary hazardous component.

\subsubsection{Laboratory Safety Assessment}

The safety assessment provides essential comparative safety and risk information for making the site selection. The assessment includes general requirements in DOE $5481.1 \mathrm{~B}$; i.e., facility hazard classification, process safety evaluation and risk assessment, transportation risk assessment, nuclear criticality safety concern, and external events evaluation (earthquake, wind, etc.).

The assessment serves as the first step for a more specific and detailed safety analysis to be initiated after site selection. A Preliminary Safety Analysis Report (PSAR) shall be completed and approved prior to the start of construction and site preparation (consistent with DOE 4700.1). The Final Safety Analysis Report (FSAR) shall be developed during the construction phase of the project and shall be completed and approved prior to the initiation of facility operations.

\subsubsection{Facility Hazard Classification}

Based on DOE 5481.1B, a facility can be qualitatively classified into one of the following three classes:

(1) Low - Those which present minor onsite and negligible offsite impacts to people or the environment;

(2) Moderate - Those which present considerable potential onsite impacts to people or the environment, but at most only minor offsite impacts; and

(3) High - Those with the potential for onsite or offsite impacts to large numbers of persons or for major impacts to the environment. 


\section{WHC-SD-WM-ES-336 REV O}

Westinghouse Hanford Company determines the facility hazard classification using the quantitative criteria in terms of onsite and offsite radiological consequence, toxicological consequence, and environmental impact.

The most important factors for determining facility hazard classification are the quantity of hazardous source and distance of receptor away the source. The decision to locate the proposed facility within the Hanford site is a sound one. Even a low-hazard laboratory, if located close to a population center, could produce undue risk to the public.

The total quantity of the hazardous materials to be processed can be administratively controlled to maintain the laboratory as a low-hazard facility. Proper operating safety 7 imits can also be imposed as additional safety barrier to control the process flow and storage of the hazardous material.

\subsubsection{Facility Process Safety}

The purpose of the safety evaluation and risk assessment of a process is to identify the bounding envelope of consequences for credible accidents scenarios and to assess probabilistic risks associated with accident events. No specific effort has been made at this time to characterize the behavior of the proposed facility under accident conditions. In the next stage of analysis (PSAR) after site selection, the risk assessment of the proposed facility will be developed to provide a profile of the potential accidents and the response of the facility to those accidents. A spectrum of scenarios will be developed, ranging from high-probability, low consequence accidents to low-probability, high-consequence accidents.

\subsubsection{Transportation Risk} factors:

The risk of transporting hazardous materials depends on following

- Packaging performance qualification

- Characteristics, quantity, and configuration of the hazardous materials

- Type of transporting means

- Viable transportation accident database

- Consequence to workers and the pubtic

- Administrative controls during shipping, including speed 1 imit, fire protection and prevention, criticality safety, training, etc.

The packaging and criticality standards for shipping radioactive waste samples to and from the proposed facility will be in full compliance with the DOE 5480.3 requirements. As a result, the risk of releasing hazardous materials in traffic accident conditions is expected to be acceptably low. However, under very severe traffic accident conditions, release of hazardous material is still possible. Since all the packaging is certified according to appropriate types and classifications, only severe transportation accidents could potentially cause release. 
The proposed facility is expected to handle approximately 3,000 samples annualiy. Assuming that the number of samples to be processed is proportional to its existing onsite TRU waste volume, the total number of annual shipments can then be estimated based on 15 samples per shipment. In reality, variations may exist depending on the needs.

While the construction and operation may not pose a significant risk to the environment or public health, the handling and transportation of alpha contaminated waste samples possibly could present a consequential risk, especially from an accident based evaluation.

Distance from the facility to the analytical facility becomes a factor for packaging and delivery of the sample. Sites within the boundaries of 200$W$ are less impacted since they are within the same boundary. Sites at the 200-E area will required additional security and safeguards during transportation between sites. The 300 area will be impacted the most due to transportation over public roads. This may require higher security and safeguards during shipments between 300 area and the analytical facility.

\subsubsection{Nuclear Criticality Safety}

The proposed facility will be designed as such that no more than one third minimum critical mass of fissile materials are contained at the same time. At each task area and module, the fissile material will be controlled to an amount even less than the minimum critical mass. Therefore, nuclear criticality is not expected to be a safety concern for the proposed facility.

\subsubsection{External Events}

Besides transportation risk, externally initiated events, such as earthquake and wind, for each site provide unique insights about added risk and/or construction cost. These risks are evaluated for the selected site in their individual Safety Analysis.

\subsubsection{NEPA Requirements}

The NEPA process for this project may involve preparation of an EIS with appropriate review and comment by the public and by government agencies. This procedure is followed to ensure all reasonable alternatives and environmental issues are addressed and carefully considered before a decision is made.

While the construction and operation of the proposed laboratory may not pose a significant risk to the environment or public health, the handling and transportation of alpha contaminated waste samples for analysis could present a risk, especially from an accident based evaluation.

\subsubsection{Radioactive Haste Management}

DOE order 5820.2A establishes policies, guidelines, and minimum requirements by which the Department of Energy (DOE) manages its radioactive and mixed waste and contaminated facilities. Radioactive and mixed wastes will be managed in a manner that assures protection of the health and safety 
of the public, DOE, and contractor employees, and the environment. The generation, treatment, storage, transportation, and/or disposal of radioactive wastes, and the other pollutants or hazardous substances they contain, shall be accomplished in a manner that minimizes the generation of such wastes across program office functions and complies with a71 applicable Federal, State, and 10cal environmental, safety, and health laws and regulations and DOE requirements

\subsubsection{Safeguards and Security}

Safeguards and security requirements will be established in accordance with DOE Order 5632.1A The purpose of the Department of Energy (DOE) Safeguards and Security program is to establish policies for the physical protection of security interests and baseline. physical protection standards. The Department's security interests are to be protected from theft or diversion of special nuclear material (SNM), industrial sabotage, radiological matter or Government property, and other hostile acts which may cause unacceptable adverse impacts on national security or on the health and safety of the public. This facility will not contain any. SNM material and shall be taken into consideration. Specific policies and objectives, as identified in this Order series, are expressed in terms of what is required. Levels of protection appropriate to particular security interests are to be provided in a graded fashion in accordance with the potential risks to national security and the health and safety of the public.

\subsubsection{QuaTity Assurance}

Quality Assurance requirements will be in accordance with DOE Order $5700.6 \mathrm{C}$. The purpose of the Quality Assurance program is to provide Department of Energy (DOE) policy, set forth requirements, and assign responsibilities for establishing, implementing, and maintaining plans and actions to assure quality achievement in DOE programs. This Order applies to a 71 DOE programs including those directed toward siting, design, construction, testing, operation, maintenance, and decommissioning of facilities;

development and production of materials, components and systems; and acquisition of research and technology data.

\subsubsection{Turnaround Time}

Assuming 1 imited quantity and Type A packaging are used, the operational time period for loading, unloading, quality control, and handing should not exceed one day per package.

A maximum of 12 days for ful1. process control results should be achievable. Full sample data package turnaround witl average 100 days and preliminary report will be prepared in two weeks time.

\subsubsection{Material. Storage and Transport Systems}

As many as 750-1,250 samples may be in inventory at any given time. The storage and delivery of this 7 arge number of samples can be easily accomplistied with existing technology. A standard sample carrier/container 
would have to be developed to serve as the common interface to the various handling devices, storage systems and workstations.

\subsubsection{Site Waste Processing Support Requirements}

In addition to waste characterization of buried TRU mixed waste, the facility must support new waste processing programs. Although many of these programs are still in the planning phase, and analysis support requirements cannot be quantified at this time, the general nature of the programs can be identified.

The Waste Receiving and Processing Facility (WRAP), scheduled to be operational in FY 1997, will process waste bound for WIPP. Opening waste containers, removing waste materials, sorting, inspection and sampling, size reduction, repackaging for shipment to WIPP, etc. This processing will result in additional TRU mixed waste samples.

In order to operate with minimum in-house inventories of Waste-In-Process, rapid sample analysis turnaround cycle time is necessary. It is expected that the aggregate sample analyses requirements of all the TRU waste processing activities may be several thousand per year. This fairly large number of priority samples highlights the benefits of automation.

\subsection{ALTERNATIVES}

\subsubsection{Offsite Laboratories (LITCO, LANL, Argonne East)}

With the risks involved, political and public, the shipment of hazardous or radioactive material, even analytical samples across state borders, is not recommended. Also due to time constraints on protocols for analysis, off site analysis is not feasible. Cost requirements for packaging and transportation are significantly higher for off site than for local shipments. This alternative is no longer considered.

ALTERNATIVE: N/A

COST: $N / A$

\subsubsection{Hanford}

Several facilities at the Hanford site offer possibilities for providing support handling transuranic waste analysis. These facilities are described below.

\subsubsection{Fuels and Materials Examination Facility (FMEF)}

This facility is in the stages of permanent shutdown and any attempt to utilize a portion of the building will require significant expenditures for operations. Milestone M-81-00 calls for transition to be completed by December 2001. Systems such as ventilation, electrical, heating and cooling, 
utilities and services would have to be operated, maintained and funded by the Tone occupant. The essential services and maintenance burden has been estimated at $\$ 2,300,000$ per year. This type of financial burden makes this alternative unacceptable as a resolution and will not be considered any further.

ALTERNATIVE: N/A

COST: N/A

\subsubsection{Plutonium Finishing P1ant (PFP)}

PFP, located in the 200 West Area, first began operating in 1951. The plant processed plutonium bearing chemical solutions, converting them to metals and oxides. PFP production stopped in 1989. A milestone date for clean out will not be set until a National Environmental Policy Act environmental impact statement and record of decision is issued in June 1996.

The PFP facility has the capability to provide front end separations and full analysis. Information to support this option has been requested, but was unavailable at the time of publication. A potential exists that the building base burden may be assigned to the laboratory. The functions for the laboratory may require separation from the function of the PFP 1aboratory. A cost is estimated and is used in the evaluation with no supporting basis.

ALTERNATIVE: Interim and Long Term

INTERIM COST: $\$ 1,500,000$ (ROM Est.)

LONG TERM COST: Unknown

\section{$5.3 .2 .3 \quad 231-Z$}

Due to the age and historical use, the facility has been directed to proceed with decontamination and decommissioning: The facility is not to be used for occupancy in the future. This option will not be considered any further.

ALTERNATIVE: N/A

COST: N/A

\subsubsection{Plutonium Uranium Extraction Facility (PUREX)}

The PUREX plant was built in 1955 to recover plutonium and uranium from reactor fuels. The facility operated from 1956 to 1972 and from 1983 to 1990. A decision to shut down was made in 1992. The transition (milestone M-80-00) will reduce utilities to the building and consolidating ventilation systems by July 1998. No further activities will be permitted in the building after FY 1998.

The PUREX 1aboratory has the capability to provide an interim and a long term solution for the analytical needs for TRU waste. The PUREX 1aboratory has six laboratory rooms (approximately $600 \mathrm{~m}^{2}$ ) with 53 hoods, an equipment decontamination room, sample storage caves, high level waste facility, high level sample handling capability, stockroom, and supporting offices (approximately $60 \mathrm{~m}^{2}$ ). The laboratory has a separate ventilation system, 
loading dock for shipping and receiving of samples, and a permitted laboratory aqueous waste tank.

The facility has a 400 gram plutonium limit for the laboratory. This quantity is in excess of the requirement for the TRU 1aboratory. The SAR limitations appear to be in excess of the limits that would be posed on the TRU Tab. This may require a change to downgrade the SAR for that portion of the PUREX site that will be dedicated to TRU analysis. Analytical procedures and operating procedures are presently in place for handling TRU waste. A laboratory information management systems (LIMS) is in place for monitoring analytical results and tracking samples.

Modifications will be required to isolate the PUREX laboratory from the main facility. New Motor Control Centers would be required with extensive wiring changes. Heating could be accomplished by installing new steam 7 ines, electric heat $(650 \mathrm{~kW})$ or a heat pump. Replacement of a sanitary water line will be required. A new collection tank for liquid waste would be required or the liquid waste would be collected and 1 ab packed. New fence line with lockable entrances would be required to isolate the facility. The fire system would require evaluation for upgrades, but the system is separate. Several hoods would require removal and disposal and gloveboxes would be installed. Room modifications would be required to convert four rooms into one room. The potential of being assigned the full building burden for utilities and for surveillance is a high risk and would not be an acceptable condition.

ALTERNATIVE: Interim and Long Term

INTERIM COST: $\$ 4,000,000$

LONG TERM COST: $\$ 7,500,000$

\subsubsection{T-Plant}

T-Plant offers a capability as an interim laboratory for the separation of alpha and gamma constituents before the samples are transported to the 222$S$ facility for analysis.

The T-Plant facility began operations in 1944 and changed mission to a decontamination facility in 1957. A portion of the facility called the "Head End" has been used as a laboratory in the past and is presently unoccupied. The facility is presently in the process of isolating services to this portion of the building. The water services have been isolated and the steam system is to be isolated in the near future. The head end portion of the plant has its own separate ventilation system.

The head end facility consists of a laboratory with six hoods with ventilation and a small hot cell with manipulators on the main floor. Also on the main floor is a lunch room and several office areas. Another laboratory is located on the lower floor and several offices are located on the upper floor. The facility is in need of repair and cleanup to accommodate the proposed interim facility. These include removal and disposal of five hoods, decontamination of the area, installation of three gloveboxes, lighting, ventilation, office upgrades and conversion of an area for a change room with a shower. A new loading dock and parking area upgrade with outside lighting would also be required. The lower laboratory is not considered as being required for this option and would not require modification or cleanup. This area can be used in the future if space is required. 
Transportation and packaging costs will impact the operational costs for this facility. T-Plant is located within the boundaries of 200-West as is the 222-S facility. Samples will require packaging to be moved between

facilities. The packaging can be standardized and reused to reduce costs. Transportation within the 200 -West area wi1l be less restrictive than if the facilities were required to transport across public roads.

The Safety Analysis Report would require to be addressed to include the activities of the proposed head end facility.

ALTERNATIVE: Interim

INTERIM COST: $\$ 1,600,000$ - Estimate File No: Z304SAAI

\subsubsection{6 $\mathrm{UO}_{3}$}

This facility is in an accelerated phase of decontamination and decommissioning and not available for future occupancy. The target date for completing transition and beginning Surveillance and Maintenance is June 1995. The facility has completed deactivation and is ready to turn the facility over to the ERC surplus facilities program for eventual decommissioning. This option will not be considered any further.

ALTERNATIVE: N/A

COST: N/A

\subsubsection{325 Building}

The 325 building may have the capability and capacity to provide front end separations and full analysis of TRU. waste samples. The building burden for the use of 325 Building is a potential concern. Also the overhead for PNL services is higher at this time. A major advantage to this option is that transuranic analytical capability could be incorporated with very little expense and in a very timely manner.

The 325 facility has been notified that funding for the facility may not be supported in the future. This decision is still an undecided issue. If the 325 building remains supported as it has been in the. past, then only the interim option may apply. If. it is not supported then it has the capability to provide long term support. Until this decision is made this study will assume that the facility is available for both options.

ALTERNATIVE: Interim and Long Term

COST: TBD

\subsubsection{222-S Complex}

This facility offers a full operational laboratory with staff and infrastructure to accommodate a full range of analytical services. The facility is operated 24 hours per day, seven days per week. The off-shifts are at a much reduced staffing level due to sample work load levels do not require full time staffing. The facility is restricted to 177 grams of plutonium to ensure that a criticality is not capable of occurring. This 


\section{WHC-SD-WM-ES-336 REV 0}

requirement will remain to prevent changes to the safety documentation for the 222-S facility.

The 222-S Hot Cell facility has potential to provide an interim solution. Space is available at the hot cell to place two glove boxes without interference with normal operations. This option has the advantage of being close to the hot cell if needed and has all required services available, modifications would be required for connection to the glove boxes.

Ventilation is sufficient, but modifications would be required for connection. Waste handling operations is already present within the 222-5 facility. Transportation risks are minimized by placing this service at the 222-S facility.

For a long term solution the facility would require a separate structure to perform the initial sample preparation. This front end structure would separate the alpha and gamma constituents from the sample prior to releasing the sample for analysis at the 222-S facility. The distance from the 222-S facility that this structure would need to be built will depend upon the safety classification of the new structure and the impact it might have on the classification of the existing facility.

This alternative offers a long term solution to the needs of the Hanford Site. The 222-S facility is scheduled to be in service until 2025. At that time the existing facility is scheduled to be replaced with a new 7 ab.

ALTERNATIVE: Interim and Long Term

LONG TERM COST: $\$ 5,000,000$ - Estimate File No. Z293SAAI

INTERIM COST: $\$ 750,000-$ ROM

\subsubsection{New Facility}

A new facility to handle transuranic sample analysis will provide sufficient space for the required sample load with capability for expansion. The location of a new facility could be located close to the majority of the sample source at the WRAP facility, thereby eliminating the majority of the transportation risks. This alternative has previously been studied and evaluated in the Waste Analys is Laboratory engineering study WHC-SD-WM-ES-190, dated 10/25/91. A draft Functional Design Criteria document was also prepared, WHC-SD-WM-FDC-021, dated 10/91. The physical size of the building can be reduced from $57,300 \mathrm{~m}^{2}\left(188,000 \mathrm{ft}^{2}\right)$ to $5,730 \mathrm{~m}^{2}\left(18,800 \mathrm{ft}^{2}\right)$.

ALTERNATIVE: Long Term

LONG TERM COST: $\$ 32,000,000$ - Based on 1991 Estimate and Escalated to 1995 Dollars

\subsubsection{Outsourcing}

Although commercial laboratories can be used to supplement during the transition period, no commercial laboratory currently has the capability or capacity required to handle samples greater than or equal to $200 \mathrm{nCi} / \mathrm{g}$. Most facilities are in heavily populated urban areas and, together with the total requirement for offsite shipping, several safety assessment areas would be negatively impacted. It is also likely that an EIS process would be required at one or more of the commercial laboratories. This alternative is not 


\section{WHC-SD-WH-ES-336 REV 0}

considered as an acceptable resolution to the Hanford transuranic sampling requirements and will not be considered any further.

ALTERNATIVE: N/A '

COST: $N / A$ 


\section{HHC-SD-WM-ES-336 REV 0}

\subsection{DISCUSSION OF PREFERRED ALTERNATIVE/SOLUTION}

Al1 alternatives were evaluated for interim resolution and long term resolution against the criteria described in Section 5.1.1 through 5.1.5. These evaluations are shown in the tables below. The alternative with the highest total is the preferred alternative for that solution.

The alternative selected for the interim solution is to modify room $11 \mathrm{~A}$ (Hot Cell Addition) on the west side of the building and south of the last analytical cell (Figure 1). The modification will required ventilation, electrical and services to two glove boxes.

The 222-S facility offers the advantage of being located at the facility that the analytical work will be performed. This location eliminates the transportation risk of having to package and ship the prepared sample to the lab for analytical work. By placing two glove boxes in the new hot cell room at $222-S$, the aggressive operational schedule could be met with the least amount of construction of any other alternative. It is assumed that two glove boxes can be obtained from the excess equipment at the FFTF facility. This will reduce equipment costs. Placing the operation within the 222-S facility will prevent duplication of effort and burden of additional services that other facilities could not provide. The additional work area and procedures will comply with the existing safety conditions in the hot cell area.

This alternative does not provide the total space outlined in the criteria section. Space for a third glove box is needed if the sample projections are met or increase. However, for the initial years, the two glove boxes will satisfy the projected needs. If required, additional shifts could be imposed to handle increased sample projections. Additionally, if space becomes available in the future at the facility a third glove box may be installed. This option has the potential of evolving into a permanent solution with operational experience and sample flow stabilization. By placement in room 11A, an analytical cell may also be available. The analytical cell has inherited restrictions by requiring all work to be done remotely and access to the cell is more restricted.

The preferred alternative has the capacity of meeting the needs of the solid waste program by FY 1997 at the most reasonable cost and schedule. The long term alternative is not recommended at this time due to budget and sample projection changes. 
WHC-SD-WM-ES-336 REV 0

FIGURE 1

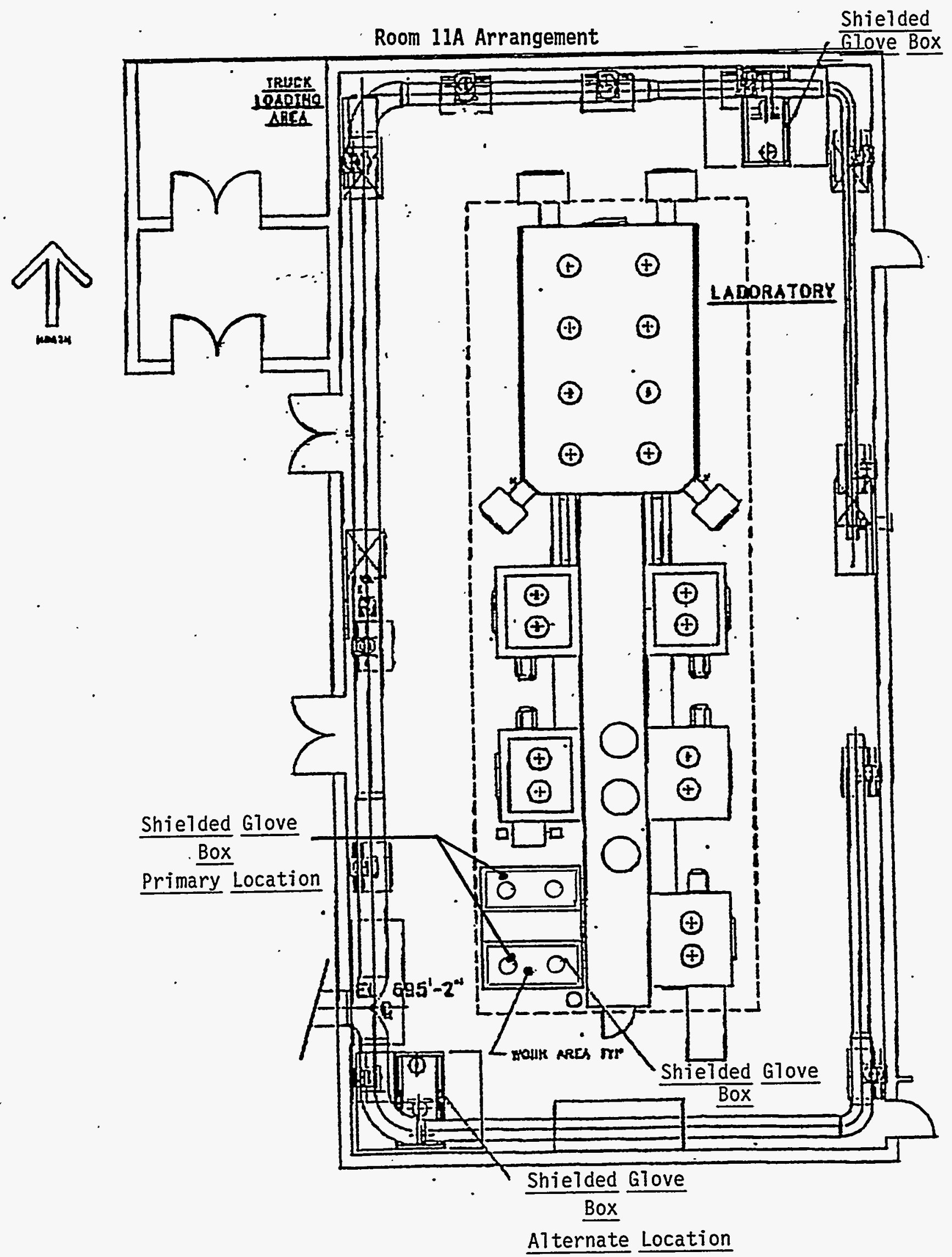




\section{WHC-SD-HH-ES-336 REV 0}

\subsection{NO ACTION ALTERNATIVE}

ReguTatory Commitments for the Environmental Restoration and Waste Management programs preclude this alternative since the existing laboratory

facilities cannot handle the expected requirements. 


\section{WHC-SD-WM-ES-336 REV 0}

\subsection{REFERENCES}

1. SNML-89-021, Preliminary Safety Analysis Report (Draft), Special Nuclear Materials Research and Development Laboratory Replacement Project 2(88D-105), Los Alamos National Laboratory, December 1989.

2. DOE/RW-0006, Integrated Data Base for 1990: U.S. Spent Fuel and Radioactive Waste Inventories, Projections, and Characteristics, Rev. 6, October 1990.

3. SLA-74-0001, Severities of Transportation Accidents, 4 Volumes, RK Clarke, et al., Sandia National Laboratory, September 1976.

4. UCRL-15910, Design and Evaluation Guidelines for Department of Energy Facilities Subjected to Natural Phenomena Hazards, RP Kennedy, SA Short, JR McDonald, MS McCann and RC Murray, Office of the Assistant Secretary for Environment, Safety and Health Office of Nuclear Safety, U.S. Department of Energy, 1988.

5. UCRL 53582, Natural Phenomena Hazards Modeling Project: Seismic Hazard Models for Department of Energy Sites, Rev. 1, Lawrence Livermore National Laboratory, Livermore, California, 1984.

6. UCRL 53526, Natural Phenomena Hazards Modeling Project: Extreme Wind/Tornado Hazard Models for Department of Energy Sites, Rev. 1, Lawrence Livermore National Laboratory, Livermore, California, 1984.

7. UCRL 53851, Natural Phenomena Hazards Modeling Project: Flood Hazard Models for Department of Energy Sites, Rev. 1, Lawrence Livermore National Laboratory, Livermore, California, 1988.

8. DOE/NBM-1058, DOE Transportation Facility Guide, Transportation Operations and Traffic Management, U.S. Department of Energy, Washington, D.C., 1991.

9. DOE/S-0078P, Environmental Restoration and Waste Management Five-Year Plan, Fiscal Years 1992-1996, June 1990.

10. DOE/CE-007T, Environmenta7 Restoration and Waste Management Robotics Techno7ogy Deve7opment Program Robotics 5-Year Program P7an.

11. United States Environmental Protection Agency, 1986, Test Methods for Evaluation Solid Waste, Volume 1, Sections A, B, C, Publication Nol SW846, Third Edition.

12. John P. Sibilia, A Guide to Materials Characterization and Chemical Analysis, N Pubijshers, Inc., 1988.

13. Venetz, T. J., 1995, Interface Control Document Between Analytica7 Services and Solid Waste Disposal Division, WHC-SD-WM-PICD-005, Rev. 0, Westinghouse Hanford Company, Richland, Washington

Code of Federal Requlations (CFRs)

40 CFR 136

10 CFR 
49 CFR 172, 173, 178

49 CFR 177,825

40 CFR 268

10 CFR 1021

40 CFR 1500-1508

\section{DOE Directives}

DOE 4700.1, Project Management System

DOE 5480.5 Safety of Nuclear Facilities

DOE 5481.1B Safety Analysis and Review System

DOE 5632.1A Protection Program Operations

DOE 5700.6B Quality Assurance

DOE 5820.2A Radioactive Waste Management

DOE 1540.1

DOE 1540.2

Materials Transportation and Traffic Management

Hazardous Material Packaging for Transport - Administrative Procedures

DOE 5480.3 Safety Requirements for the Packaging and Transportation of Hazardous Materials, Hazardous Substances, and Hazardous Wastes

DOE 4240.1 Designation of Major System Acquisitions and Major Projects

DOE 6430.1A General Design Criteria 
WHC-SD-WM-ES-336 REV 0

\subsection{APPENDIXES}

\section{APPENDIX A}

Projected Annual Waste Production

\begin{tabular}{|c|c|c|c|}
\hline Waste Category & Liquids & Solids & Other \\
\hline $\begin{array}{l}\text { Non-Radioactive } \\
\text { Non-Hazardous }\end{array}$ & $\begin{array}{l}\text { About } 40 \mathrm{~L} / \mathrm{yr} \text { will be } \\
\text { absorbed and disposed of } \\
\text { as solid waste. Most } \\
\text { cooling water will be } \\
\text { recirculated. }\end{array}$ & $\begin{array}{l}\text { No quantity estimate } \\
\text { available; office paper, } \\
\text { plastic, boxes, crates, } \\
\text { wrapping, metal. }\end{array}$ & $\begin{array}{l}\text { Recjclable: } \\
730 \mathrm{~kg} \text { toner } \\
\text { cartridges } \\
730 \mathrm{~kg} \text { office paper } \\
730 \mathrm{~kg} \mathrm{Al} \text { cans } \\
\end{array}$ \\
\hline $\begin{array}{l}\text { Non-Radioactive, } \\
\text { Hazardous }\end{array}$ & $\begin{array}{l}400 \mathrm{~kg} \text {; chemicals, } \\
\text { reagents, spills, } \\
\text { solvents, glues, paints }\end{array}$ & $\begin{array}{l}400 \mathrm{~kg} \text {; chemicals, } \\
\text { incandescent light } \\
\text { bulbs, grease, rags, } \\
\text { tile cement, caulking } \\
\text { compounds }\end{array}$ & \\
\hline $\begin{array}{l}\text { Mixed (Radioactive \& } \\
\text { Hazardous) }\end{array}$ & $\begin{array}{l}\text { Aqueous: } 20,000 \mathrm{~L} / \mathrm{yr} \\
\text { with an estimated } \\
\text { activity of } 2 \mathrm{E}-04 \mathrm{Ci} / \mathrm{L} \text {; } \\
\text { waste stream to tank } \\
\text { farms - corrosive acid } \\
\text { or base with no organic } \\
\text { material, with other } \\
\text { regulated materials in } \\
\text { solution (heavy metals, } \\
\text { etc.) } \\
\text { Organic: } 20 \text { labpack } \\
\text { drums at } 12 \text { L/drum }=600 \\
\mathrm{~L} \text { with an estimated } \\
\text { activity of } 50 \text { to } 1000 \\
\text { pCi/g; methylene } \\
\text { chloride, hexane, } \\
\text { alcohols, scintiliation } \\
\text { liquids, ToC coulometer } \\
\text { solutions. }\end{array}$ & $\begin{array}{l}10 \text { drums } 0208 \mathrm{~L} / \mathrm{drum}- \\
2,100 \mathrm{~L} \text { with } 0.5 \text { to } 100 \\
\text { mRem/hr at contact, } \\
\text { estimated activity } 5 \mathrm{E}-04 \\
\text { to } 1 \mathrm{E}-03 \mathrm{Ci} / \text { drum, } \\
\text { average weight } 40 \\
\text { kg/drum; containers, Tab } \\
\text { instruments, paper } \\
\text { towels, gloves. }\end{array}$ & \\
\hline
\end{tabular}


WHC-SD-WM-ES-336 REV 0

\begin{tabular}{||l|l||}
\hline $\begin{array}{l}\text { Radioactive } \\
\text { (Non-Hazardous) }\end{array}$ & $480 \mathrm{~m}^{3}$ (uncompacted) with \\
0.2 to $100 \mathrm{mRem} / \mathrm{hr}$ at \\
contact, estimated \\
activity 5E-04 to $1 \mathrm{E}-03$ \\
Ci/drum average weight \\
$70 \mathrm{~kg}$ of waste/drum; \\
glassware, metals, \\
plastic, rubber, wood, \\
floor tile, equipment, \\
demolition waste, and \\
compatible waste (1/2 of \\
total).
\end{tabular}

